\title{
Russian Cinema in the Free-Market Realm
}

\author{
By Christina Stojanova
}

Spring 1999 Issue of KINEMA

RUSSIAN CINEMA IN THE FREE-MARKET REALM: STRATEGIES FOR SURVIVAL

For a motto of this article I would like to paraphrase the title of Werner Herzog's 1974 film Jeder für sich und Gott gegen alle ${ }^{1)}$ (Every Man for Himself and God Against All) to read: Every Director for Himself and the Free Market Against All.

The Hungarian-born social economist and philosopher Karl Polanyi provides a useful theoretical framework for the current situation in post-Communist national cinemas. In his ground-breaking work The Great Transformation: The Political and Economic Origins of Our Time (1944) he critiques the inherent tendency of an all powerful market to subordinate and manipulate society. His famous dictum "laissez-faire was planned, central planning was not" rings more true today on the basis of post Communist experience, than at the time he wrote his book between the wars. ${ }^{(2)}$

Polanyi has consistently warned against the dangers of separation -- or "disembedding" -- of the economy from the social, cultural and political sphere. The perils of marketisation of society, the process of rampant commodification is "only a short formula for the liquidation of every and any cultural institution in an organic society."

As far as post-Communist states and elites are concerned, not much has been done to protect the social fabric against the onslaught of the neo-liberal strategies, especially in the cultural sphere.

The situation in Russian cinema follows the general pattern characteristics of the cinema crisis that has plagued the other post-communist countries -- Americanisation of the repertoire, dismantling of the state budget, lack of private investment, collapse of the traditional distribution network and of the film-production structure.

The massive and unchecked influx of American films after 1989, held for so long beyond the ideological pale, has been quoted as one of the major reasons for the current crisis. American films took over the repertoire, occupying around $75 \%$ of the programming time, with a tendency to reach $85 \%$ during the next decade. At the same time the number of film theatres in the Russian Federation has dwindled from 3000 to 1500 , and continues to fall. (The data here is taken from the 1995 bulletin of Eureka Audiovisuelle) ${ }^{(3)}$

It seems, however, that the Americanisation of the Russian film scene does not represent the most serious threat. In an interview I took last year from Andrei Plakhov, ${ }^{(4)}$ President of the Russian section of FIPRESCI, ${ }^{(5)}$ and a vice-president of FIPRESCI as of this year, he said, and I quote:

"Americanisation is not the greatest threat. American films are all over the place, and even more so in the eastern part of Europe, because audiences are still very interested to see films that were completely off-limits before. Our society, however, seems to have come through this period of uncritical interest to American cinema relatively fast, due to the accelerated development of all cultural processes world-wide. In the western part of the world or at least of Europe it took many years for audiences to realise they have had enough of Hollywood, while in our country it took only a few years and now we can evaluate the results. The majority of the people have turned away from American cinema. The cinemas are empty, people just do not go to cinema anymore... To sum up -- I do not see particularly disturbing signs of Americanisation of the Russian film scene, and therefore do not perceive it as a danger."

Another major factor for the crisis of Russian cinema seems to be the fundamental change of attitude towards cinema. It certainly is geared to the collapse of the distribution network, but there are also others, specific social factors at play. As A. Plakhov says, "We certainly can find lots of explanations: tickets are expensive for both young and old, it is dangerous to leave home in the evening because of raging criminals etc., but the basic problem is that people have changed their attitude during these few years. Going to the cinema was like a ritual in Soviet times, it was perceived as a social event: families used to go to the cinema on Sundays with or without their children. But now this is over: people prefer to see films at home on video or TV, they 
don't see the need to go to theatres where the conditions aren't very accommodating anyway. It might be also because of the poor technical quality of the screening. In Russia we don't have Dolby systems, not even subtitles. We have American films with Russian dubbing (or voice over) which is absolutely terrible and I do not know how people put up with it."

Unlike Western European countries where the tradition of cinema going is still alive and well, and surely quite contrary to the situation in North America where people go to cinema on a very regular basis, people in Russia seem to have lost the habit or the desire to do so. It is not that Russians have entirely lost interest in their own cinema -- the circulation of popular film magazines and journals, concentrating on Russia's own cinema world, is steady and even has slightly risen. ${ }^{(6)}$ As Plakhov puts it, "I believe it is because of the broken psychological pattern, because of the habit that has been was destroyed. Sergei Bodrov's film Prisoner of the Mountain (1996, dir. S. Bodrov) was shown in a very good theatre right downtown St. Petersburg, on Nevski Prospect, but it was empty, no viewers... ."

The breakdown of the traditional production apparatus is the third major reason for the crisis of the postCommunist national cinema, along with drastic reduction of state subsidies and lack of private investment. After the production boom in Russia from the early 1990s (300 films for 1991-92 alone), the figure has dropped after a brief stabilisation at around 50-60 per year for 1994-95, and continues to fall drastically. To say that the government has entirely ceased to finance Russian cinema will be wrong. But the traditional mismanagement of government funding, the need to support an enormous army of already redundant administrators, and pay salaries to tenured, not working film-makers has rendered government funding far from sufficient vis-à-vis inflation and constantly rising costs. Paradoxically, even big and well funded film productions, instead of keeping the money at home, prefer to shoot and do the post-production in other countries, preferably at Barrandov Studios in Prague. It is safer, it is better organised, and most important -- it is much cheaper than at home.

There is however a fourth major reason for this crisis, dating back to the times of Communist censorship and self-censorship -- lack of serious concern and even contempt for the so-called mass viewer. Filmmakers were never worried about box-office returns -- they either benefited from the captive audiences, or were engaged in a complicated game of hide-and-seek with authorities. Hungarian social philosopher Miklos Haraszti (in his essay "The Velvet prison") describes this situation as the joys of the "uneconomic liberation" of Communist culture. He claims that Eastern intelligentsia's fascination with Communism comes from its deep insecurity vis-à-vis the stern supply-and-demand considerations of the market.

Karl Polanyi -- on the basis of lessons, drawn from society's inevitable effort to protect itself against the onslaught of the free market -- claims that the history of free market is history of "double movement": the strategies of the deliberately imposed laissez-faire economy, on one hand, and the protective countermovements of society against its disruptive effects, on the other. For if market economy represents a threat to human and natural components of the social fabric, Polanyi claims, "what else would one expect than an urge on the part of a great variety of people to press for some sort of protection? ${ }^{(7)}$ Paradoxically, Eastern European film-makers -- Russian included -- are faced with the urgent need to find a "protective" strategy, an aesthetic "counter-movement" which would allow them to beat the market on its own terrain. In other words, they are trying to find the Ariadne's tread that will allow them to preserve their artistic integrity, the national specificity of their cinemas, and win back the lost viewer en masse.

The basic purpose of this paper is to pinpoint some aesthetic counter-movements and protective strategies that have come about as a result of the crisis in all post-Communist countries.

The first and most natural wave of cultural self-protectionism, or aesthetic counter-movement, is the wave of films, meant to release pent up dissident energies from the times of totalitarianism. Most of them appeared in the interim period and benefited from the best of both worlds -- state subsidies and total freedom of artistic expression. These films were overburdened with heavy metaphors, and spoke in an almost hermetic film language. They engaged passionately in breaking taboos -- mainly sexual and political, which is kind of strange for they were basically knocking on open doors. Given the poor record of experimental cinema under Communism, these films could at their best be classified as experimental and avant-garde, and at worst -as incomprehensible, self-serving psychotherapy, exorcising complexes and fears from the Communist era. ${ }^{(8)}$ 
Notwithstanding the dubious artistic value of most of these films, they reflect the profound crisis of selfawareness that has beset Communist societies on both personal and public level. For they also represent a catalogue of inhibited and uninhibited myths and counter-myths of the collective unconscious that keep reproducing themselves and have turned into a source of perpetuating frustrations after the fall of Communism. Leningrad underground trend, called significantly Necrorealism, belongs here, so does the wave of film parodies and conceptual remakes.

As I have analysed extensively this trend in my article The New Russian Cinema and the New Russian Society ${ }^{(9)}$ and in series of articles about post-Communist Central and Eastern European cinema, I will not elaborate further on the cultural etymology and on the later developments of this trend. I would only like to point out the basic similarities between the Russian and the East-Central European post-Communist avant-garde: this is a phenomenon that has brought the principles of "dissident" auteur cinema, and of the traditional elitism of Eastern European culture ad absurdum. Vis-à-vis the new economic and social realities, such total neglect for the viewer -- any viewer -- could easily be described as suicidal.

Another form of protective strategy is the genre of co-production. I will try to touch on this genre here, on the basis of Nana Djordjadze's film A Chef in Love, scripted by her husband Irakly Kvirikadze and will try to expose some of its most important features and mishaps in the process of discussing other issues. This, however, would be far from sufficient, bearing in mind the rather diverse character and stable popularity of this "genre". The concept of genre is justified here in a broad sense -- meaning a cluster of films demonstrating a sufficient number of stable characteristics of form and style. As Aristotle, who cannot be accused of lacking in method, said that every object must be studied with the precision appropriate to it.

It is a common fact that co-production could be a rather controversial endeavour. A film-maker has to have the strong artistic personality of Irakly Kvirikadze and Nana Djordjadze and know how to get around the demands of the producers, get together a first rate crew and make their own film. Otherwise they could easily be enticed into recycling the images and ideas of their previous films -- the films that made them famous, that is. Or even worse -- co-production could entrap filmmakers to serve as mediators of political agendas and ideas, suggested by producers or agencies. There is an inherent danger here, particularly serious for small national cinemas. In relying too heavily on foreign financing, directors are prone to give up their artistic freedom and compound the crisis of their national cinemas, initiated by the negligence of the local cultural institutions.

The only "good" thing that has emerged after the initial fascination with co-production has subsided is the understanding of its nature as a difficult business relationship. Directors have become increasingly aware that the diktat of foreign producers is not that much different from the diktat of the former Communist authorities. The pressure to look for the magic formula of a universally marketable hybrid, made with Western money and Eastern European, respectively, Russian sensitivity, is no less taxing than the pressure to create art, national in form and socialist in content. Such requirements usually end up with rather sorrowful results. And more often than not the product is an artistic oxymoron, reinforcing mostly negative stereotypes about "those Russians" or "those Eastern Europeans." Nana's film is not quite safe from mis-apprehension. The tragic-comic quest of her Chef in Love is intertwined with situations referring to, or directly quoting from the good old "Georgian film school". And on this level the film could indeed provoke an ah-those-Georgians type of reaction, but it is so well crafted artistically and so elegantly ironic that such a reaction would probably be meant as a compliment. Nana Djordjadze's film, along with Yosseliani's latest opus, Brigands, Chapter VII (1996) -- another positive example of the genre -- incorporate, deconstruct, or simply reproduce archetypes, motifs and icons from the 60s, 70s and early 80s Georgian films about chudaki (wonder-mongers).

It cannot be otherwise for these productions are expected to adapt trendy Western ideas to the radically different social mores and cultural climate in post-Communist countries. And the chances for a flop are much higher than for a success. It is enough to mention Y. Mamin's film Window in Paris (1995), S. Bodrov' s The Russians (1992) as evidence of cultural incompatibility. As the targeted audience is usually rather hypothetical, and culturally extremely diverse, the film could be intriguing only for immigrant viewers who are familiar with the cultural stereotypes from both sides of the co-production venture. Neither purely Western nor Russian audiences can fully enjoy these films for they are neither here nor there in the literal sense of the term. And conversely, analysing how skilfully directors have succeeded to fit their own original 
ideas and style within the requirements of the producers, and to organically blend them, represents an interesting critical and sociological exercise.

Certainly, famous directors from former Communist countries stand the best chances to get Western funding. But Western producers, from their end, have no interest in promoting a foreign cinema -- money these days is scarce to be spent on philanthropy. To justify the expenses, the producers have to demonstrate that the subject matter of the future film is somehow related to their own national culture. That would further justify the selection of actors, shooting sites, language etc. Needless to say, it is an extremely difficult exercise for the film-makers. Nana Djordjadze and Irakly Kvirikadze, however, have a good experience to fall back on -the success of their film My English Grandfather (1990) which made a favourable impression at festivals all over the world. This time around they have repeated the recipe more successfully.

Thus Nana Djordjadze has created the ultimate co-production oeuvre, financed almost entirely by French sources. There is no doubt she has successfully met the expectations of her producers -- besides all the good press and awards, her film received an Oscar nomination for a best foreign film in 1997. It is national in spirit, international in content and ideologically eclectic. Only the rich artistic imagination of the team Djordjadze-Kvirikadze could justify such a mish-mash of entirely incompatible ideas and genre approaches, and pull out a perfectly enjoyable film. There is no need to deliberately separate the original themes, ideas and motifs from those born from co-production considerations -- a simple reference to the plot neatly exposes the demarcation line.

A young, educated and independent Georgian Princess (Nana Kirtadze) goes back to her pre-Revolutionary Georgia. On the train she meets a French Cook (Pierre Richard), much older than herself, but an extremely charming man with a fascinating past. In no time they fall madly in love and enjoy life with Renaissance gusto and abandonment -- the beauty of Georgian nature, the wine, the cuisine. And certainly sex -and a lot of it! The romantic comedy, however, turns into a bleak satire once the Bolshevik Revolution erupts. The images of Bolsheviks, real and imaginary, are actually caricatures. Catering to basic derogatory stereotypes, Kvirikadze and Djordjadze have pictured them as promiscuous alcoholics, thugs and traitors of the rich Georgian language, culture and independence. The legendary Alexandra Kolontai, the first woman to become a minister in the Bolshevik government, is portrayed as a cruel, ugly and arrogant nymphomaniac, apparently to counter-balance the ephemeral beauty and style of the Princess. It is a sinister juxtaposition and a form of revenge of a macho culture that could accept women's liberation only in case they remain "princesses" of beauty and love, but never as symbols of power.

A young Bolshevik Commissar, a typical Georgian macho and former high-way thief, has had an eye on the Princess and uses his newly acquired power to force her into marriage. On the backdrop of escalating Bolshevik violence and lawlessness, the continuing romance of the Princess and the Cook ends up in tragedy: the Commissar kills the Princess out of jealousy but not before she has born a son. The Cook dies from grief. In another reversal of roles and stereotypes the film-makers give credit to democratic and liberal values -- it is the "bourgeois" Cook who shows tolerance and understanding for "free" love, while the jealous communist commissar is the arrogant macho chauvinist.

All these events are set in a contemporary framework, justifying the French financial participation. As an elderly man, the Princess's son is in Paris, arranging an art exhibition of the famous Georgian master Pirosmani. There he meets a relative of the Cook and while going through her family archives -- in a good old melodramatic reversal of fortunes -- he finds out that his real father was the Cook, not the Commissar.

To wrap it up: as it is, the success of co-production is largely motivated by the previous success and popularity of the national cinema and /or individual national directors. If those run their course and become irrevocable history, if the post-Communist national cinemas fail to produce new indigenous masters and pieces, the coproduction will simply disappear as an alternative to globalization. A third, much more reliable protective strategy has emerged in post-Communist national cinemas. I have called it elsewhere the "Quest for the Viewer." ${ }^{(10)}$ It is characterised with creation of new genres, based on skilful adaptation of American genre formulas to post-Communist reality. The "Quest for the Viewer" has also brought about the revival of old, nearly forgotten genres, like melodrama. This trend is discussed here on the basis of two new films from Russia -- Sergei Bodrov's Prisoner of the Mountain (1996) and Alexander Balabanov's Brother (1997). 
Prisoner of the Mountain has borrowed the genre of the anti-war movie from the classic European cinema from the 30s, or more specifically, from The Great Illusion (1938, dir. Jean Renoir). It is also strongly influenced by the American anti-war movies from the 70s and 80s. It is a most suitable artistic operation for the representation of the fratricidal war in Chechnya. Brother, on the other hand, has borrowed the genre of the gangster film, and falls into the category of what I have called elsewhere Mafiosi thriller. ${ }^{(11)}$

These two films accidentally represent principle modes of internal, self-reliant financing in Russia. Prisoner of the Mountain is financed mostly by a private producer, Boris Geller. A former student of Bodrov's from VGIK, he is currently a millionaire businessman in Kazakhstan. And, since according to Nikita Mikhalkov "there is no 'clean' money in today's Russia", one is compelled to agree that it is much better if some newly acquired wealth is spent on keeping a branch of the national culture going, instead of being mindlessly wasted in Cote Lazur. Brother is produced by Goskino of the Russian Federation in conjunction with the semi-private company STV.

Before going any further, I would like to address briefly the question of genre as a response to the demands of the market, on one hand, and on the other -- as a vehicle for auteur artistic expression. The anti-war film in its American version and especially the gangster movie belong to the so called formula films -- the answer of the American cinema to the standardisation drive of the market towards mass production of goods. But if standardisation is easier to accept in the case of the production of, let us say, refrigerators, in the case of works of art it is individualism and originality that make all the difference. The old dispute, pitting mass accessibility of popular genre movies against the high art elitism of auteur cinema is the best illustration of this perceived dichotomy. With the advent of post-modernism, however, both genre and auteur approach came to be considered merely tools for more adequate understanding and appreciation of cinema, rather than expression of a priori value judgment. Genre scholars came gradually to agree that the auteur principle of originality and the formula requirements of a genre do not necessarily contradict each other and that in fact in the hands of auteurs genres are enriched and flourish. What makes a genre study interesting is not the inventarisation of its stable characteristics, but the artistic contribution, made by an individual director -- who could be considered an auteur if the process is creative. In our case the director's contribution is extremely important. These two films demonstrate with great deal of artistic integrity the trappings of auteur contribution, born out of the necessity to reconcile the specificity of a national culture with the requirements of a pan-European -- or global -- market. A necessity which has almost become a virtue.

The basic problem with the adequate adaptation of foreign genre structures is that it puts to the test professional modes, moral and social mores. The attempts of the Polish cinema to emulate American gangster film are overall successful -- and I have in mind here the series of films that followed the 1992 success of Pigs (dir. W. Pasikowski). This success is even more valuable bearing in mind that the traditions of the classical Soviet film school, and the officially imposed Socialist Realist aesthetics have largely shaped Eastern European filmmaking over almost half a century. The classical Soviet cinema generally favours slow-paced genres and the so called psychological camera -- that is a slow moving one, with preference for close-ups -- as well as meticulous artificial lighting. Tight story line, suspense building, location shooting, fast-paced editing, and the ability to reveal a character in one or two big strokes -- the basic prerogatives of the American genre cinema -- used to be considered as lesser artistic means. And therefore -- non-representative.

Secondly, Communism left a legacy of total confusion of values, and in the absence of at least nominal consensus on what the dominant values of the post-Communist society are, it is difficult to work within genre formulae. For genre formulae are, by their very nature, closer to traditions and often times reproduce stereotypes. They tend to even be conservative and fall back on what has generally -- and repeatedly -been accepted by society as right or wrong, good or bad. And genre formula always activates archetypes and favours recurring visual and conceptual motifs; narrative structures; familiar character types; repeated images and even self-quotes.

The sociological importance of a genre film stems from the transparency of social values and mores, predominant at the time of its creation. And, conversely, a genre formula gets modified and evolves under the pressure of changing social values and mores. When the "social values and mores" are the result of completely different historical and politico-economic circumstances, the modifications of the genre are even more revealing and challenging -- both ideologically and artistically. 


\section{The Politically Correct Approach}

S. Bodrov's artistic contribution to the anti-war genre, or rather -- to its successful adaptation on Russian soil, is the way he succeeds in overcoming the afore mentioned moral ambiguities, and confusion of values. He does that by juxtaposing character types and symbolic images, derived from the war films from the Soviet era, with characters knowable from the great classics of the anti-war film genre. The anti-war message is born from the clash and/or bi-polarity on the level of ideas, of characters and on the level of discourse. The major divide between the characters is their attitude towards war, and to the enemy -- actual or perceived.

The principle set of characters are Sasha (Oleg Menshikov) -- a low-ranking army officer, and the GI Ivan Zhilin (S. Bodrov, Jr.) During the very first combat in which Zhilin and Sasha take part, they are ambushed and captured by the Chechen Abdul and his men to be later exchanged for Abdul's only son, who is imprisoned by the Russians. While in captivity, the two men get to know each other better. During their second attempt to escape, Sasha is killed. In the meantime, Ivan's mother arrives and tries to convince the stubborn Russian Army colonel to go for the exchange, and save her son. Something goes terribly wrong, and Abdul's son is killed. Abdul's daughter Dina unsuccessfully tries to help Ivan flee. Abdul takes Ivan to shoot him, but changes his mind and releases him at the moment when Russian helicopters are approaching the village -- in the style of Apocalypse Now -- with the apparent intention to bomb it out of existence.

Sasha is knowable from numerous Soviet war films and displays the archetypal features of the traditional Soviet cinematic war hero. In fact, his cinematic pedigree is emphasized by the marches that are being played in the background of his close-ups, and by the little refrain he hums and whistles -- about the girl, left behind and her blue scarf -- a familiar tune from numerous WWII movies. The cinematic tradition adds one more (stereo)typical feature to his character: he has grown up in an orphanage, so the army is in fact not only his profession, but also his home. True to this image, Sasha is brave to the point of recklessness.

Bodrov de-mythologises him by exposing the hollow pomposity of his behaviour on the backdrop of this absurd war. He is a devout patriot and has no doubts whatsoever concerning the war -- as long as it is a war, waged by Mother Russia and its Army, it is a just one. Bodrov questions this traditionally noble trait by making him verbalise violently racist ideas regarding their Chechen captors.

Zhilin, on the other hand, is a typical post-Soviet Russian youth, a boy next door, the only son of a devoted mother -- one who gets recruited at a time when so many dodge the mandatory service. There is nothing outstanding or charismatic about him -- in fact, he is so plain that Sasha keeps forgetting his name. Ivan Zhilin, however, is a true hero -- or rather -- anti-hero -- of his time. His character antecedents go back to the heroes from All Quiet on the Western Front, The Great Illusion, Hair. Like them, he is a pacifist not out of ideological or religious conviction, but spontaneously, for he feels a strong kinship with these Caucasian villagers -- after all, they all were Soviet citizens until very recently. And in spite of the imprisonment, he somehow cannot perceive the war as real neither the villagers as enemies: he strikes a friendship with the beautiful young daughter of the awesome Abdul, and becomes known amongst the villagers as an amicable and skilful watch-repairer.

In a deliberate reversal of roles and expectations, provoked by the new political and social context, it is Sasha who perishes, and Ivan who survives. Thus the value system of the Soviet war movie and its limitations, symbolised by Sasha, are challenged in the name of a truly pacifist attitude, displayed by Zhilin.

Most interesting amongst the secondary characters are the images of the two women in Zhilin's life: his mother and Dina. It should be noted that women's roles are very scarce these days in Russian cinema. Besides, the genre under scrutiny is perceived traditionally as male. Again, the images of the two women represent a pair: a Soviet cinematic stereotype and an imported image, borrowed from the anti-war genre.

The Mother is the archetypal soldier's mother, known from so many Soviet war films. She has raised her only son alone and with great sacrifices. Only to see him off to the front -- to fight, and eventually die for the motherland. In addition, she is a teacher who proudly reads her son's letters to her students. This, too, is knowable from numerous films and paintings about WWII. On a symbolic level she is the image of Mother Russia and her perennial suffering.

Dina, on the other hand, is a neo-romantic character. It is easy to relate her to Lotte from The Great Illusion, the young German woman who Jean Gabin's POW falls in love with. This love and the phrase "Lotte hat 
blaue Augen"(12) -- the only other phrase, besides Streng Verboten ${ }^{(13)}$ that the run-away POW can muster in German -- have come to constitute one of the most powerful anti-war messages, delivered in film.

Dina is also a very real Soviet girl. She is coping with the role, imposed on her by the generation of her father -- that of a young female Muslim whose only perspective is to get married. Bodrov let us know, however, that she has quite a character, and can stand for herself in a truly liberated fashion. He also suggests that Muslim fundamentalism is unlikely to flourish if more girls flaunt Dina's independent mind and strong spirit.

The importance and place of women in such a male genre as the anti-war film is defined vis-à-vis the principle character. The mother fails in her attempt to help Ivan. It is Dina and her love that saves him. In yet another deliberate reversal of Soviet roles and stereotypes, the traditional image of the mother as saviour loses against the presumably hostile stranger. The fact that Dina probably perishes in the helicopter attack amplifies the transcendental meaning of her gesture.

The images of enemies, in accordance with the best traditions of the anti-war film genre, and against the stereotype of the Soviet war movies, are well balanced, detailed and represent different political and ideological background. This adds yet another dimension to the film's strong message. Abdul's character is related to that of Eric von Stroheim's noble enemy -- the German colonel from The Great Illusion. He is a man of honour and of his word, and this confronts him tragically with the tribal hostility of the other village elders, and with the young thugs who take war as just another source of easy money and easy life.

\section{The Politically Incorrect Approach}

The gangster film was born at the time of trouble in US -- the Great Depression -- and is most suitable for maximum adequate representation of society when the Old is no more and the New has not yet appeared; to reflect the tensions between the New Rich and the New poor. Alexander Balabanov's adaptation of the gangster thriller to the post-Soviet Russian reality has more sociological than artistic relevance. Bodrov sets the conflicts, the characters and the passions of a local war into the critical perspective of a democratic, bi-polar discourse or a dialogue, demonstrating his political and moral sensibility. Balabanov, on the other hand, identifies fully with his protagonist, and aggressively justifies the one-sidedness of his outlook. The structure of the film could be defined as structure of confrontation (in Salesman's terms), where the hero enters and exits the narrative without suffering any change or development, serving as a mediator of Heaven against the forces of Hell. Accordingly, all characters are divided, in strictly Manichenian fashion, into friends and enemies of the hero, into black and white. This is one of the most popular genre schemes as it allows for the action to take over character developments.

The hero (again Sergei Bodrov, Jr., who is swiftly becoming the first real star of New Russian Cinema) is discharged from the army and returns home, to his mom. Although he insists he had served in HQ, it becomes clear very soon that he is a seasoned warrior, and has most probably served in special units, deployed in Chechnya. Following his mother's advice, he goes to his brother who has "made it" in Petersburg. It turns out the brother is a killer for hire. The brother tries to recruit our hero, but the hero has his own agenda -along with ambiguous attitude towards Jews and gays, and active resentment for people from the Caucasian Republics, it turns out he hates Mafiosi and their thugs, and begins to act as a self-proclaimed saviour of society, combining elements of Robert De Niro's and Schwarzenegger's social avengers ( Taxi Driver and Total Recall come to mind).

The narrative is simple, linear and predictably follows the rules of the genre. What is interesting and challenging is to trace the genre's motifs, icons and archetypes in the context of contemporary Russian reality. The hero is well placed in the social space and time: we learn all we need to know while the titles are still running: he is arrested for beating badly the director of a video clip that is been shot in his native town, that his father was a convict and had died in prison, and that the boy comes from very humble background.

The hero's love for music is an important structural element. Actually, the director has acknowledged that Batusov, the soloist/composer of the popular rock group Nautilus, played an instrumental role in the making of the film. The film actually works also as an overblown video-clip of Nautilus. Many episodes and characters are introduced only to service this function.

True to the genre imperatives, the hero heads off to the big city, which -- again in tune with the genre, is an evil place: thugs dominate the market place, "persons of Caucasian origin" behave outrageously, refusing to 
pay their fines to a Russian tram ticket controller, etc. The hero certainly wants to get up in the world, to be well dressed, and to be an integral part of the crowd of Nautilus admirers. And takes on the first "job" his brother offers him for he needs the money. Strangely enough, a junkie named Kat becomes his companion in the hype St. Petersburg's world. Kat's presence as definitely functional: a video clip has to be as inclusive as possible.

The episodes with Kat work also on another level -- to allow the hero to express his negative sentiments towards American music and Americans in general. Only in Kat's social milieu could he encounter a foreigner -- a Frenchman who he mistakes for American to tell him that American music is "shit" as compared to Nautilus, and that the Russians "would soon wipe the smile off their faces." These "patriotic" remarks, along with those against gays, Jews and the "black-assed" Caucasians, do not add much to the image of the hero, and lose their edge in Bodrov's interpretation. His strength is in his warm, manly charisma and empathic screen presence, not that much in what he is saying. But these remarks surely are meant to bring him closer to that part of Russian audience who does share such ideas and thoughts.

The hero is not in love with Kat -- as a true muzhik (man) he needs a baba (a mature woman), not a fashionable doll. And the $b a b a$ he finds -- her name is Sveta -- evokes the image of a Soviet working woman with a character, reminding of the images of women, created by Lyudmila Gurchenko and Inna Churikova in the 70s and 80s. Her husband is a drunk, her marriage loveless, her job is hard and masculine -- she drives a cargo mortise; and lives in a communal apartment. She is not very beautiful either, and is much older than the hero. But she has a heart of gold, and this is what matters. This openly melodramatic story line takes the film straight to the door of female viewers. The fact that the relationship is not about sex, but about the hero cum protector and provider, is especially effective for the success of the film. This is what majority of women in Russia, as the most deprived part of the population, need in these times of trouble.

On the other hand, the director caters to male chauvinistic sentiment as well. And introduces the episode of Sveta's rape by Mafiosi. It is supposed to be a vengeance for the actions of the hero, but in fact works as punishment for her marital infidelity. And while there is no explicit sex on screen, the beating and eventual rape of Sveta are rather graphic. The rape scene also provides the dramatic impetus for the key episode of the film, a direct quote from so many gangster films. The hero, under the sounds of a Nautilus song, prepares meticulously his weapon, dresses to kill and appears like the avenging angel to save his brother at the last minute. Bodrov is not very good as an action hero -- he is a bit slow and not very accomplished physically. But he has a magnetic and nuanced presence, and it is much more interesting to contemplate him prepare for action, and in the aftermath, then just watch him shoot his enemies at point blank.

Women are of no great importance to the hero, although he is nice and caring to both of them. Neither they are sex objects, although he obviously sleeps with both. The hero, in tune with the requirements of the genre, is chaste and generous. Women are a valuable acquisition, a status symbol, like the expensive clothes he wears, or the electronic equipment he buys for his baba, or the drugs and the expensive booze for Kat. He is, however, an ascetic, a loner -- most of all he values friendship, love and human solidarity, but -- in accordance with the genre -- he is much better off on his own.

The motif of betrayal is very important for the genre. The hero is usually faced with the urgency to forgive or avenge an act of betrayal. Here the hero generously forgives his brother who had used him and had set a trap for him. But the call of blood has always been a very important element in Russian culture, and has recently been vindicated after the long repression of the terror-imposed allegiances to Party and Communist ideals. Not only the hero forgives his brother -- he also gives him money, advises him to go back to their old mom, and eventually take a job with the police as he is of no use in the underground world. The hero's reference to the police brings in another important image from the original gangster movie -- that of the authorities. An image, that is totally absent from Brother. Excluding the hero's brief encounter with the police at the beginning, after initiating a brawl on the shooting site of a Nautilus video-clip, police or any other representatives of the official power are never seen or referred to. A very appropriate and more than adequate reflection of the reign of lawlessness in present-day Russia.

The friends and supporters of the hero, are people poor and/or weak, harassed by Mafia, forgotten by the state and generally -- social outcasts with hearts of gold. They are the people, who -- again in tune with the genre -- are the victims of the notorious lawlessness and random violence in post-Communist Russia, most 
in need of the hero's protection.

The Mafiosi themselves are not differentiated by the director. In accordance with the rules of the genre, they act and look interchangeable. A crowd of villains, who deserve to be slaughtered by the hero. Only one of them, the Boss, is individualised -- he speaks in proverbs, and is identified, significantly, as a former Komsomol activist.

Certainly, the reference to "purely Russian contemporary myths and ideas" is the principle contribution of this film to the Mafiosi thriller. As the American journalist Vladimir Voina pointed out in his article on Brother, ${ }^{(14)}$ audiences outside Russia would have hard time to relate to all this misogyny, male chauvinism, to remarks, suggestive of xenophobia, bigotry and homophobia. But, as the hero's friend, the German, says -- "What is good for a Russian, can kill a German." In order to understand what is "good for the Russian," the film has to be judged according to its own laws -- and as such, in the words of Voina, this "film is an adequate expression of the popular Russian ideas of the 'hero of our time'".

In a way of conclusion I would like to note that the desire of Russian filmmakers to reach vast national audience is a commendable attempt to stand up to the challenges of the Globalization of the film market. Whether these attempts could be qualified as genuine aesthetic counter-movements or are just expedient strategies for survival is too early to judge. What is important is the attempt to preserve the national specificity of their films as art, and as a tool of social and psychological cognition, no matter how controversial.

(Revised Draft. Presented at the 29th Annual AAASS Conference, Seattle, November 1997)

\section{Notes}

1. The English title is The Enigma of Kaspar Hauser

2. Polanyi, Karl. (1944). The Great Transformation, (Boston; Beacon Press), p. 159.

3. Eureka Audiovisuelle is a Bruxelles-based agency, funded by EU to support and promote European film art. It is affiliated with Eurimages.

4. Published in Montreal journal for film theory and criticism Ciné-bulles, vol. 15 \# 3, pp. 38-42.

5. FIPRESCI -- Fédération internationale de la presse cinématographique. Founded in 1930. FIPRESCI was given the mandate to "affirm the freedom of the critic" and to "promote the idea of cinema as a means of artistic expression, for influencing the culture and civic conscience." FIPRESCI includes about fifty national organisations of film critics.

6. On the basis of info, published in Seans, 1997.

7. K. Polanyi, op. cit., p. 150. 8. There is certainly a group of highly artistic works, like Oleg Kovalov's films, but they are beside the point.

9. Published in French in Ciné-Bulles, Vol. 14, No. 1, pp. 12-16; and in English in Kinema Fall 1998.

10. In publications on Panorama of Post-Communist Cinema, Une Nouvelle Europe -- A New Europe: Reeling After the Fall. (The Panorama was curated by myself.) The term "Quest for the Viewer" is used in my curatorial statements, published in La Revue de la Cinémathèque Québécoise, March, 1997; Cinematheque Ontario Program Guide,7., No. 3; and in the article Une Nouvelle Europe, published in Cine-bulles, $16 .$, No 3 , pp. 38-41.

11. In the article "Une nouvelle Europe," Ciné-bulles, 16, No. 3, pp. 38-41.

12. Lotte has blues eyes. 13. Strictly prohibited.

14. Published in issues No. 4 of the Sochi ' 97 Film Festival newspaper, p. 2. 


\section{Author Information}

Christina STOJANOVA teaches at the Department of Media Production and Studies at the University of Regina, Canada. She has contributed to Cine-bulles, KinoKultura, and the Montreal Gazette. Her publications include chapters in Berlin Culturescapes, Making it Like a Man: Canadian Masculinities, Eastern European Cinema, Traditions in World Cinema, Horror International, Alternative Europe and Cinema and Globalization. 